\title{
Cultivation of maize in different environments and their effects on agronomic traits
}

\author{
Ivan Ricardo Carvalho', ${ }^{1}$, Francisco Goi Eickhoff ${ }^{1}\left(\mathbb{D}\right.$, Tiago Silveira da Silva' ${ }^{1}$, Adriano Dietterle \\ Schulz ${ }^{1}{ }^{\circ}$, Rafael Soares Ourique ${ }^{1}\left(\mathbb{D}\right.$, Tainá Froncek Malheiros ${ }^{1}\left(\mathbb{D}\right.$, Felipe da Rosa Foguesatto ${ }^{1}{ }^{\circ}$, \\ Marlon Vinicius da Rosa Sarturi' ${ }^{1}$, Murilo Vieira Loro' ${ }^{1}\left({ }^{\circ}\right.$ and Danieli Jacoboski Hutra' ${ }^{1}$ \\ ${ }^{1}$ Universidade Regional do Noroeste do Estado do Rio Grande do Sul (UNIJUÍ), CEP 98700-000, ljuí, Brazil, *Corresponding author, E- \\ mail: carvalho.irc@gmail.com
}

\begin{abstract}
The objective of this work was to show which traits are influenced by the interaction genotype $\mathrm{x}$ irrigated environment, to reveal trends of linear associations in each environment and to identify genotypic variation through canonical variable analysis in maize. The experiment was conducted in Campos Borges - RS. The experimental design used was randomized blocks organized in a factorial scheme, being two cultivation environment (dry environment characterized only by the availability of rainwater; irrigated environment where a $15 \mathrm{~mm}$ layer of water was applied ten days apart the crop cycle, from seedling emergence to physiological maturity stage) $\times 13$ hybrids of maize, arranged in three replicates. The traits plant height, insertion of ear height, mass of one thousand grains and grains yield are influenced by the genotypes $x$ environments interaction. The irrigated environment presents superiority in relation to dry environment for all the traits studied. In general, the genotype G9 performs better than others. The irrigated environment presents superiority than dry environment, in relation to the traits plant height, insertion of ear height, mass of one thousand grains, grain yield per hectare, ear length, ear diameter, ear mass, grains mass per ear and number of grains per ear row.
\end{abstract}

Keywords: Management hydric, biometrical models, yield components, human food, genetical enhancement, irrigation management.

\section{INTRODUCTION}

The production of maize (Zea mays L.) in Brazil reached 81.5 million tons in the 2014/2015 harvest season, making Brazil to figure among the three largest producers of this crop, together with reaching United States and China. Regarding its use as raw material, Brazil occupies the fourth place (Sauer et al., 2015; United state Department of Agriculture [USDA], 2016; Santos, Bizzarri, Barbosa, \& Zucareli, 2017). The economic and social importance of this cereal is a consequence of its high grain yield per unit area and adaptation to different regions, as well as numerous properties/utilities for foods and feeds, such as high nutritional value (Sousa, Bastos, Cardoso, Ribeiro, \& Brito, 2015; Demari et al., 2018; Szareski et al., 2018; Rosa et al., 2020).

Grain yield in maize can be influenced by several factors of genotype (open pollinated varieties or hybrids) and environmental origins. Hybrids are preferred in large properties that present high technological level, appropriate infrastructure, availability of nutritional and water resources and edaphoclimatic conditions (Baretta et al., 2017; Nardino et al., 2017). The range of influence of genotypic and environmental factors when different genotypes and environments are compared is described as genotype $x$ environment ( $G \mathrm{XE}$ ) interaction (Carvalho, Souza, Follmann, Nardino, \& Schmidt, 2014; Nardino et al., 2016a).

The influence of agronomical traits on grain yield varies, however, there is a certain ranking in the degree of influence to increase grain yield. Therefore, the components that contribute to yield are defined as primary and secondary. Primary and secondary components present direct and indirect effects on grain yield, respectively. The primary components are composed by the agronomic traits weight of a hundred grains and number of grains per plant (Leng, 1954). Secondary components are traits such as plant height, ear height, culm diameter and tassel dry matter (Schnell and Cockerham, 1992) using as references the evaluation of the traits with indirect effect on yield.

Irrigation management applied in the phenological stages, such as pre-flowering to grain filling, effectively 
contributes for the grain yield. The accumulation of water in the flowering and filling stages of grains results in the maintenance of plant tissues such. Therefore, irrigation is essential for maintenance of water in the tissues, and one needs to identify the water demand that will be necessary for it to reach all functional systems. It is known that the maize cycle needs 577 millimeters of water to achieve adequate yield, while the pre-flowering phenological stage is the one that requires the most water, being its consumption around 7 millimeters per day (Bergamaschi et al., 2001).

It is of utmost importance to use the linear associations for the identification of correlations and select the traits that have indirect effects on the yield components (Carvalho, Lorencetti, \& Benin, 2004). The irrigation constitutes a viable alternative for increasing yield, meeting the water needs of the crop, mainly, in times of drought (Lopes, Oliveira, Souto-Filho, Goes, \& Camacho, 2011). Increases up to 39\% in hybrid yields in Rio Grande do Sul were observed with irrigation management. However, the more precise this management, the better the performance of commercial hybrids, avoiding the occurrence of water deficit during the cycle (Carvalho et al., 2014). Therefore, the objective of this work was to show which traits are influenced by the interaction genotype $\mathrm{x}$ irrigated environment, to reveal trends of linear associations in each environment and to identify genotypic variation through canonical variable analysis in maize.

\section{MATERIALS AND METHODS}

The experiment was conducted in the 2013/2014 harvest season in the county of Campos Borges - RS, with latitude of $28.55^{\prime} 36,02^{\prime \prime} \mathrm{S}$, longitude of $53 \circ 01^{\prime} 40,34^{\prime \prime} \mathrm{W}$ and with altitude of 513 meters, on soil described as Latosol dark red (Empresa Brasileira de Pesquisa Agropecuária [EMBRAPA], 2006). The climate described by Köppen as Cfa subtropical and altitude of 513 meters.

The experimental design used was randomized blocks organized in a factorial scheme, being two cultivation environment (dry environment and irrigated environment) $\times 13$ hybrids of maize, arranged in three replicates. Rainfall distribution for the months between May 2012 and April 2013 is shown in Figure 1.

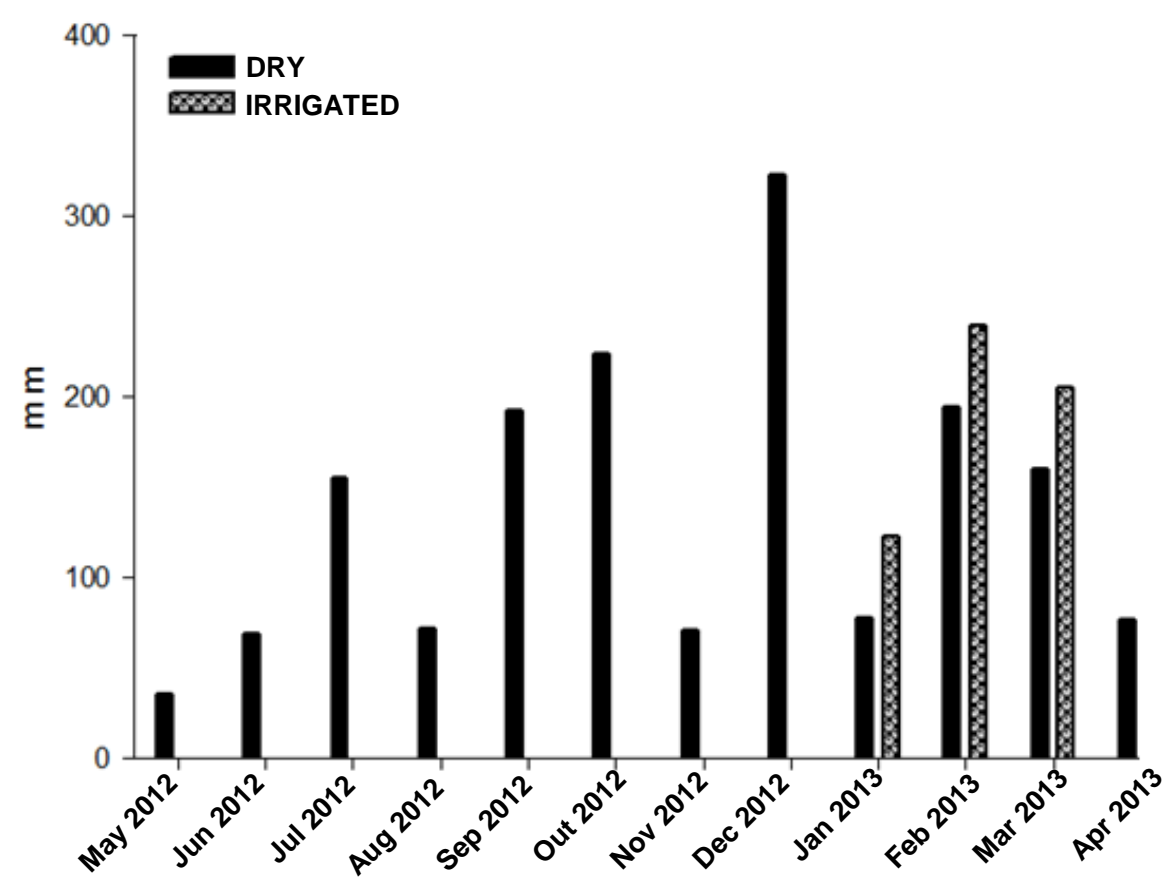

Figure 1: Rainfall distribution for the months between May, 2012 and April, 2013.

The genotypes of maize used were classified according to their genetic constitution, all being single hybrids: AG $9045^{\circ}$ (G11), AG 9045 RR PRO $^{\circ}$ (G7), AS 1572 PRO $^{\circ}$ (G12), AS 1656 PRO2 $^{\circ}$ (G6), DKB 245 PRO $^{\circ}$ (G5), DKB $250 \mathrm{PRO}^{\circ}(\mathrm{G} 4), \mathrm{DKB} 285^{\circ}$ (G1), KSP1356 (G9), P1630 (G8), P2530 (G13), STATUS ${ }^{\circ}(\mathrm{G} 2), 2 \mathrm{~A} 106^{\circ}(\mathrm{G} 3)^{\circ}$ and $30 \mathrm{~F} 53^{\circ}(\mathrm{G} 10)$.

The cultivation environments used were: dry, only with the rainfall available, and irrigated, where there was an application of one water layer of $15 \mathrm{~mm}$ with an interval of ten days during the crop cycle, emergence of seedlings until the stage of physiological maturity. 
The experimental units were composed by four rows $5 \mathrm{~m}$ long and spaced by $0.5 \mathrm{~m}$, being considered useful plot the three central lines where the interest traits were measured. The population density used was 75,000 plants ha- ${ }^{-1}$ in direct seeding system with basic fertilization of $350 \mathrm{Kg} \mathrm{ha}^{-1}$ of NPK in the formulation 10-20-20 and $300 \mathrm{Kg} \mathrm{ha}^{-1}$ of urea $(45 \% \mathrm{~N})$ as cover divided in two applications in the stages V4 and V6 of the crop (Kluthcouski, Fancelli, Dourado-Neto, Ribeiro, \& Ferraro, 2000). Phytosanitary management, which consisted in the control of pests and diseases, was carried out in a preventive manner, in order to minimize the effects on the test results.

The traits measured were:

Plant height: obtained through the measurement of the plant at the ground level to the last fully expanded leaf, results expressed in meters $(\mathrm{m})$;

Insertion of ear height: measured the distance from ground level until to the insertion node of the first ear, results expressed in meters $(\mathrm{m})$;

Ear length: determined through the measurement from basal end to the apical end of the ear, results expressed in centimeters $(\mathrm{cm})$;

Ear diameter: measured in the middle third of the ear with aid of a caliper ruler, results expressed in millimeters $(\mathrm{mm})$;

Stem diameter: performed in middle third of the stem with aid of caliper ruler, results expressed in millimeters ( $\mathrm{mm}$ );

Ear mass: obtained through the mass of three ears without straw, dividing by three and obtaining the mean for anear, with aid of digital scale, results expressed in grams (g);

Stem mass: the mass of each stem was measured, the values obtained with the aid of a digital scale; results expressed in grams (g);

Mass of one thousand grains: obtained by the count of 100 grains with eight replications for each experimental unit, with the aid of digital scale; the results were corrected to $13 \%$ moisture; results expressed in grams $(\mathrm{g})$;

Grain mass per ear: obtained through the manual threshing of three ears, computing the mean of one ear, obtained through digital scale;

After that, a sample was taken to correct the values for $13 \%$ moisture, results expressed in grams (g);

Number of ears per plant - prolificacy: obtained through the ratio between the number of plants and the number of total ears of the plot, results expressed in units (units);

Number of rows per ear: average obtained through the count of number of true rows in three ears, results expressed in units (unit); Number of grains per ear row: measured by counting the number of grains in the row of three ears from the basal to the apical end, results expressed in units (units);

Grain yield per hectare: measured by the ratio between the grain mass of each ear by the number of plants, the grain mass was then adjusted for each plant, correction for moisture content to $13 \%$, the values obtained were adjusted to the population density used; results expressed in kilograms per hectare (Kg ha-1).

Statistical analysis, the data displayed were subjected to the analysis of variance $(p \leq 0.05)$ in order to verify the assumptions. The joint analysis of variance was performed to verify the interaction between cultivation environments $x$ maize genotypes. Subsequently, when the significance for the $\mathrm{G} \times \mathrm{A}$ interaction was verified, the simple effects were dismembered and the characters that did not present significant interaction, were compared separately for each treatment factor. The traits that revealed significance were used to compose the Pearson's correlation analysis in order to verify the tendency of association for each cultivation environment. The statistical analyses were performed using the software GENES (Cruz, 2013).

\section{RESULTS AND DISCUSSION}

The analysis of variance $(p \leq 0.05)$ revealed significant interaction between the maize genotypes and cultivation environments for the traits plant height, insertion of ear height, mass of one thousand grains and grain yield. The lack of significant interaction was observed for the traits ear length, ear diameter, stem diameter, ear mass, stem mass, grain mass per ear, number of ears per plant, number of rows per ear and number of grains per row per ear. For the factor maize genotype, the traits that did not differ were stem diameter, ear mass, grain mass per ear, number of ears per plant, number of rows per ear and number of grains per ear row. On the other hand, for the factor cultivation environment the traits that did not differ were stem diameter, number of ears per plant and number of grains per ear row.

Regarding plant height, the maize hybrids performing better in the dry environment were G3, G9 and G10 
(Table 1). When in irrigated environment, the genotypes G5, G4, G2, G9 and G3 displayed better performances. The hybrid G1 showed higher plant height in dry environment, while the hybrids G5, G4, G2, G9 showed higher plant height in irrigated environment. The plant development is affected by the density of plants in the area, competition for water, nutrients and light, where the highest number of plants per area leads to an increase in plant height, increasing, consequently, the height of the ear in the plant (Calonego, Poleto, Domingues, \& Tiritan, 2011)

Regarding insertion of ear height (Table 1), the genotypes G3, G11, G5, G4 and G10 were superior under the dry environment. Under the irrigated environment, the hybrids G5, G4, G2 and G3 were superior. Environmental effects for this trait were observed in the hybrid G1, where a reduction was observed. On the other hand, in the hybrids G6, G5, G4 and G9, considerable increase in the ear height was observed under the irrigated environment.

A larger mass of one thousand grains (MTG) was observed for the hybrid G12 under the irrigated environment, while the hybrids G10, G4, G2, G1 and AS G3 better performed in the dry environment. The irrigated area provided higher MTG for all the genotypes, except for the hybrids G1 and G3.The MTG is directly linked to the productive potential of the crop and is dependent on the management practices employed, where better water conditions favor the formation, assimilation, and maturation of the grains (Carvalho et al., 2014; Nardino et al., 2016b).

Regarding the grain yield in the irrigated environment, the genotypes $G 2$ and G6 presented superior performance. The hybrids G2, G1 and G3 were statistically higher than the other genotypes in dry environment. In different environments, the maize crop presents genetic variability, requiring high water demand, radiation and temperature (Cargnelutti-Filho, Storck, Riboldi, \& Guadagnin, 2009). The irrigated environment promoted higher genotype grain yields than the dry environment, except for the hybrids G7, G13 and G3 that did not differ from the others. The water demand is one of the most essential management factors for crop production, acting in plant metabolism, growth, development and plant yields (Benjamin, Nielsen, Vigil, Mikha, \& Calderon, 2014).

Higher ear length was observed for the irrigated environment (Table 2), agreeing with Hallauer, Carena and Miranda-Filho (2010) which attributed the reduction or increase of the length of the ear to the environmental conditions that occur after flowering. For the trait ear length, the genotypes G4, G11, G6, G5, G2, G8, G1 and G10 were superior. For the ear diameter (ED), the irrigated environment promoted higher values. The genotypes G2, G3, G4, G5, G7, G8, G9, G10, G11, G12 and G13 presented the highest ED values. According to Albuquerque, Pinho, Borges, Souza-Filho and Fiorini (2008), the consumer market in natura is very demanding when it comes to ear size.

The variables $E M, G M E$ and NGR revealed that the irrigated environment is superior to the dry environment. The SM was higher in the irrigated environment, being able to emphasize the genotype G11, not significantly differing from G6, G5, G4, G2, G13, G3 and G10. Bergamaschi et al. (2004) reports that the maize tends to achieve its best development and growth, consequently its greatest productive potential, where there is optimal water disponibility for the plant.

Regarding the number of rows per ear, the genotype $\mathrm{P} 1630^{\circ}$ performance was superior to the other hybrids studied, there was no difference between the cultivation environments. These results are opposite to those obtained by Silva, Schoninger, Caione, Kuffel and Carvalho (2014) where the number of rows per ear showed an effect of the interaction between genotypes and different management. Regarding prolificacy, no difference was observed between cultivation environments, only for the hybrids studied, where G7, G12, G6, G5, G4, G2, G8, G13, G1 and G3 presented higher averages, not significantly differing among them.

The Pearson's linear correlation has the intention to measure the intensity measure of association between two variables (Carvalho et al., 2016a; Carvalho et al., 2016b). The understanding of these correlations among the variables is a tool of great importance for breeding programs, since it can be recognized whether the selection of a particular variable will cause changes in the other variables (Vencovsky, 1992).

The Pearson's linear correlation was performed for the 13 maize genotypes within each cultivation environment, with $N=39$. The linear correlation was performed for the traits $P H, E H, N E P, E D, E L, N R E, N G R$, $\mathrm{EM}, \mathrm{SD}, \mathrm{SM}, \mathrm{MTG}, \mathrm{GME}$ and GY, where 78 linear associations were observed between the traits within each environment, being 32 and 34 associations significant for dry and irrigated environment, respectively (Table 3). 
Table 1. Unfolding the interaction between the environments and hybrids of plant height (PH), insertion of ear height (EH), mass of 1000 grains (MTG) and grain yield (GY) in maize. Campos Borges, RS. 2014.

\begin{tabular}{|c|c|c|c|c|}
\hline \multirow[b]{2}{*}{ MAIZE HYBRIDS } & \multicolumn{2}{|c|}{$\mathrm{Ph}(\mathrm{m})$} & \multicolumn{2}{|c|}{$\mathrm{EH}(\mathrm{m})$} \\
\hline & IRRIGATED ENVIRONMENT & DRY ENVIRONMENT & IRRIGATED ENVIRONMENT & DRY ENVIRONMENT \\
\hline G1 ${ }^{1}-$ DKB 285 & $1.70 \mathrm{Da}^{2}$ & $1.75 \mathrm{eA}$ & $0.78 \mathrm{fA}$ & $0.86 \mathrm{dA}$ \\
\hline G2 - STATUS & $2.03 \mathrm{cA}$ & $2.03 \mathrm{bA}$ & $1.04 \mathrm{cdeA}$ & $1.15 \mathrm{abcA}$ \\
\hline G3 - 2A106 & $2.05 \mathrm{bcA}$ & $2.03 \mathrm{bA}$ & $1.04 \mathrm{cdeA}$ & $0.97 \mathrm{~cd} A$ \\
\hline G4 - DKB 250 PRO & $2.07 \mathrm{bcA}$ & $2.02 \mathrm{bA}$ & $1.12 \mathrm{bcA}$ & $0.99 \mathrm{cdB}$ \\
\hline G5 - DKB 245 PRO & $2.21 \mathrm{abA}$ & $2.05 \mathrm{bB}$ & $1.46 \mathrm{aA}$ & $1.19 \mathrm{abB}$ \\
\hline G6 - AS 1656 PRO2 & $2.28 \mathrm{aA}$ & $2.02 \mathrm{bcB}$ & $1.30 \mathrm{abA}$ & $1.15 \mathrm{abcB}$ \\
\hline G7 - AG 9045 RR PRO & $2.27 \mathrm{aA}$ & $2.05 \mathrm{bB}$ & $1.30 \mathrm{abA}$ & $1.04 \mathrm{bcdB}$ \\
\hline G8 - P1630 & $2.24 \mathrm{aA}$ & $2.09 \mathrm{abB}$ & $1.05 \mathrm{cdA}$ & $0.93 \mathrm{~dB}$ \\
\hline G9 - KSP 1356 & $1.76 \mathrm{dA}$ & $1.82 \mathrm{de} A$ & 0.93 def $A$ & $1.03 \mathrm{bcdA}$ \\
\hline G10 - 30F53 & $1.84 \mathrm{dA}$ & $1.85 \mathrm{cdeA}$ & 0.95 cdefA & $1.00 \mathrm{bcdA}$ \\
\hline G11 - AG 9045 & $1.82 \mathrm{~dB}$ & $1.98 \mathrm{bcdA}$ & 0.85 efB & $1.00 \mathrm{bcdA}$ \\
\hline G12 - AS 1572 PRO & $2.28 \mathrm{aA}$ & $2.22 \mathrm{aA}$ & $1.31 \mathrm{abA}$ & $1.29 \mathrm{aA}$ \\
\hline G13 - P2530 & $2.04 \mathrm{bcA}$ & $2.10 \mathrm{abA}$ & $1.08 \mathrm{cdA}$ & 1.13 abcdA \\
\hline \multirow[t]{2}{*}{ CV\% } & \multirow{2}{*}{\multicolumn{2}{|c|}{10.2}} & \multicolumn{2}{|l|}{9.1} \\
\hline & & & & \\
\hline MAIZE HYBRIDS & IRRIGATED ENVIRONMENT & DRY ENVIRONMENT & IRRIGATED ENVIRONMENT & DRY ENVIRONMENT \\
\hline G1 - DKB 285 & $227.64 \mathrm{fgA}$ & $158.46 \mathrm{cB}$ & $4413.64 \mathrm{hA}$ & $4224.24 \mathrm{bcdA}$ \\
\hline G2 - STATUS & 310.22 bcdeA & $155.46 \mathrm{cB}$ & 6190.77 defA & $2908.40 \mathrm{~dB}$ \\
\hline G3 - 2A106 & $436.13 \mathrm{aA}$ & $175.56 \mathrm{bcB}$ & $8370.29 \mathrm{cA}$ & $3965.92 \mathrm{cdB}$ \\
\hline G4 - DKB 250 PRO & 290.03 bcdefA & $164.85 \mathrm{bcB}$ & $10048.63 \mathrm{abA}$ & $3853.20 \mathrm{cdB}$ \\
\hline G5 - DKB 245 PRO & $359.30 \mathrm{bA}$ & $158.77 \mathrm{cB}$ & $7436.91 \mathrm{cdA}$ & $3570.45 \mathrm{cdB}$ \\
\hline G6 - AS 1656 PRO2 & $323.31 \mathrm{bcdA}$ & $191.67 \mathrm{abcB}$ & 8653.88 bcA & $3653.41 \mathrm{cdB}$ \\
\hline G7 - AG 9045 RR PRO & 341.01 bcA & 192.73 abcB & $10378.63 \mathrm{aA}$ & $5689.54 \mathrm{aB}$ \\
\hline G8 - P1630 & 254.83 defgA & $172.29 \mathrm{bcB}$ & 6008.03 defgA & $4986.24 \mathrm{abcB}$ \\
\hline G9 - KSP 1356 & 235.25 efgA & 177.54 bcB & 4642.25 ghA & $3793.93 \mathrm{cdB}$ \\
\hline G10 - 30F53 & $228.54 \mathrm{fg} A$ & $170.29 \mathrm{bcB}$ & 4626.95 ghA & $4042.25 \mathrm{cdA}$ \\
\hline G11 - AG 9045 & $206.54 \mathrm{gA}$ & 190.14 abcA & $5064.51 \mathrm{fghA}$ & 4515.79 abcA \\
\hline G12 - AS 1572 PRO & 271.93 cdefgA & $237.39 \mathrm{abA}$ & $6909.25 \mathrm{deA}$ & $5566.05 \mathrm{abB}$ \\
\hline G13 - P2530 & $324.53 \mathrm{bcd} A$ & $254.95 \mathrm{aB}$ & 5592.32 efghA & $4212.98 \mathrm{bcdB}$ \\
\hline CV\% & \multicolumn{2}{|l|}{19.2} & \multicolumn{2}{|c|}{20.4} \\
\hline
\end{tabular}

${ }^{1} \mathrm{G}$ : Genotype. ${ }^{2}$ Averages followed by the same lowercase letter in the column and upper casein the row, do not differ by Tukey test at $\mathrm{p} \leq 0.05$. 
Table 2. Average results for ear length (EL), ear diameter (ED), stem diameter (SD), ear mass (EM), stem mass(SM), grains mass per ear (GME), number of the ears per plant (NEP), number of rows per ear (NRE) and number of grains per ear row (NGR) for the environments and hybrids. Campos Borges, RS. 2014.

\begin{tabular}{|c|c|c|c|c|c|c|c|c|c|}
\hline $\begin{array}{l}\text { CULTIVATION } \\
\text { ENVIRONMENTS }\end{array}$ & $\mathrm{EL}(\mathrm{cm})$ & $\mathrm{ED}(\mathrm{mm})$ & $\begin{array}{l}\text { SD } \\
(\mathrm{mm})\end{array}$ & $\mathrm{EM}(\mathrm{g})$ & SM (g) & GME (g) & NEP (un) & NRE (un) & $\begin{array}{l}\text { NGR } \\
\text { (un) }\end{array}$ \\
\hline IRRIGATED & $16.9 a^{2}$ & $46.1 \mathrm{a}$ & $25.9 a$ & $191.0 \mathrm{a}$ & $29.8 a$ & $145.2 \mathrm{a}$ & $0.9 a$ & $15.9 \mathrm{a}$ & $35.6 \mathrm{a}$ \\
\hline DRY & $15.8 \mathrm{~b}$ & $41.2 \mathrm{~b}$ & $25.7 \mathrm{a}$ & $110.2 \mathrm{~b}$ & $18.3 \mathrm{~b}$ & $86.5 \mathrm{~b}$ & $0.9 \mathrm{a}$ & $15.7 \mathrm{a}$ & $33.1 \mathrm{~b}$ \\
\hline $\mathrm{CV} \%$ & 6.6 & 6.8 & 11.5 & 15,6 & 17.5 & 15.8 & 13.8 & 7.5 & 9.9 \\
\hline CULTIVARS & $\mathrm{EL}(\mathrm{cm})$ & $\mathrm{ED}(\mathrm{mm})$ & $\begin{array}{l}\mathrm{SD} \\
(\mathrm{mm})\end{array}$ & $\mathrm{EM}(\mathrm{g})$ & $\mathrm{SM}(\mathrm{g})$ & GME (g) & NEP (un) & NRE (un) & $\begin{array}{l}\text { NGR } \\
\text { (un) }\end{array}$ \\
\hline G1 $\mathbf{1}^{1}$ - DKB 285 & $14.9 \mathrm{de}$ & $41.9 \mathrm{ab}$ & $24.8 \mathrm{a}$ & $125.1 \mathrm{a}$ & $21.1 b$ & $95.4 \mathrm{a}$ & $0.9 a b c$ & 15.8 bcde & $34.6 \mathrm{a}$ \\
\hline G2 - STATUS & 16.9 abcde & $45.1 \mathrm{ab}$ & $27.8 \mathrm{a}$ & $173.3 \mathrm{a}$ & $36.6 \mathrm{a}$ & $125.7 \mathrm{a}$ & $0.8 \mathrm{bc}$ & 16.3 bcde & $31.6 \mathrm{a}$ \\
\hline G3 - 2A106 & 15.7 bcde & $44.5 \mathrm{ab}$ & $25.8 \mathrm{a}$ & $146.6 \mathrm{a}$ & $20.4 \mathrm{~b}$ & $117.9 \mathrm{a}$ & $0.9 a b c$ & 15.3 bcde & $36.4 \mathrm{a}$ \\
\hline G4 - DKB 250 PRO & $17.2 \mathrm{abc}$ & $40.2 \mathrm{~b}$ & $23.8 \mathrm{a}$ & $150.0 \mathrm{a}$ & $24.4 \mathrm{ab}$ & $116.8 \mathrm{a}$ & $1.1 \mathrm{ab}$ & $14.2 \mathrm{cde}$ & $36.7 a$ \\
\hline G5 - DKB 245 PRO & 16.1 abcde & $44.8 \mathrm{ab}$ & $26.4 \mathrm{a}$ & $156.8 \mathrm{a}$ & $27.3 \mathrm{ab}$ & $118.2 \mathrm{a}$ & $1.0 \mathrm{abc}$ & $16.5 \mathrm{bc}$ & $33.7 \mathrm{a}$ \\
\hline G6 - AS 1656 PRO2 & $18.1 \mathrm{a}$ & $45.6 \mathrm{ab}$ & $28.2 \mathrm{a}$ & $174.3 \mathrm{a}$ & $29.1 \mathrm{ab}$ & $134.2 \mathrm{a}$ & $1.0 \mathrm{abc}$ & $16.8 \mathrm{~b}$ & $35.4 \mathrm{a}$ \\
\hline G7 - AG 9045 RR PRO & $17.5 \mathrm{ab}$ & $42.8 \mathrm{ab}$ & $26.1 \mathrm{a}$ & $163.3 \mathrm{a}$ & $24.4 \mathrm{ab}$ & $124.5 \mathrm{a}$ & $1.0 \mathrm{abc}$ & $14.1 \mathrm{de}$ & $35.5 \mathrm{a}$ \\
\hline G8 - P1630 & $15.1 \mathrm{de}$ & $46.8 \mathrm{a}$ & $24.0 \mathrm{a}$ & $158.7 \mathrm{a}$ & $18.4 \mathrm{~b}$ & $131.8 \mathrm{a}$ & $0.8 \mathrm{c}$ & $19.8 \mathrm{a}$ & $34.3 \mathrm{a}$ \\
\hline G9 - KSP 1356 & 16.1 abcde & $43.1 \mathrm{ab}$ & $25.8 \mathrm{a}$ & $120.2 \mathrm{a}$ & $19.7 \mathrm{~b}$ & $92.2 \mathrm{a}$ & $0.8 a b c$ & $16.0 \mathrm{bcde}$ & $30.0 \mathrm{a}$ \\
\hline G10 - 30F53 & $15.8 \mathrm{cde}$ & $44.3 \mathrm{ab}$ & $26.9 a$ & $139.2 \mathrm{a}$ & $24.0 \mathrm{ab}$ & $102.7 \mathrm{a}$ & $1.0 \mathrm{abc}$ & $16.4 \mathrm{bcd}$ & $33.3 \mathrm{a}$ \\
\hline G11 - AG 9045 & $17.3 \mathrm{abc}$ & $39.9 \mathrm{~b}$ & $24.4 \mathrm{a}$ & $124.1 \mathrm{a}$ & $19.9 \mathrm{~b}$ & $98.0 \mathrm{a}$ & $1.1 \mathrm{a}$ & $14.0 \mathrm{e}$ & $34.2 \mathrm{a}$ \\
\hline G12 - AS 1572 PRO & $14.8 \mathrm{de}$ & $44.2 \mathrm{ab}$ & $24.9 a$ & 148.9 a & $23.4 \mathrm{ab}$ & $117.7 \mathrm{a}$ & $1.0 \mathrm{abc}$ & 16.3 bcde & $34.3 \mathrm{a}$ \\
\hline G13 - P2530 & $17.1 \mathrm{abcd}$ & $44.2 \mathrm{ab}$ & $26.7 \mathrm{a}$ & $177.6 \mathrm{a}$ & $25.3 \mathrm{ab}$ & $130.8 \mathrm{a}$ & $0.8 \mathrm{c}$ & $14.4 \mathrm{bcde}$ & $36.5 \mathrm{a}$ \\
\hline CV\% & 6.6 & 6.8 & 11.5 & 21.3 & 19.8 & 19.1 & 13.8 & 7.5 & 9.9 \\
\hline
\end{tabular}

${ }^{1} \mathrm{G}$ : Genotype. ${ }^{2}$ Averages followed by the same lowercase letter in the column do not differ by Tukey test at $p \leq 0.05$.

Table 3. Correlation coefficient estimates for the dry (upper diagonal) and irrigated environment (bottom diagonal) among 13 traits in maize hybrids. Campos Borges, RS. 2014.

\begin{tabular}{lccccccccccccc} 
& $\mathrm{PH}^{1}$ & $\mathrm{EH}$ & $\mathrm{NEP}$ & $\mathrm{ED}$ & $\mathrm{EL}$ & $\mathrm{NRE}$ & $\mathrm{NGR}$ & $\mathrm{EM}$ & $\mathrm{SD}$ & $\mathrm{SM}$ & $\mathrm{MTG}$ & $\mathrm{GME}$ & $\mathrm{GY}$ \\
\hline PH & & $0.62^{*}$ & -0.13 & 0.17 & 0.18 & 0.05 & 0.18 & $0.42^{*}$ & 0.10 & 0.30 & $0.46^{*}$ & $0.48^{*}$ & $0.35^{*}$ \\
EH & $0.86^{*}$ & & -0.04 & 0.16 & 0.30 & -0.05 & 242 & 0.19 & 0.19 & $0.48^{*}$ & $0.39^{*}$ & 0.27 & 0.05 \\
NEP & 0.00 & 0.08 & & $-0.41^{*}$ & 0.08 & -0.30 & 0.06 & -0.25 & -0.19 & -0.07 & -0.18 & $-0.34^{*}$ & 0.25 \\
ED & $0.44^{*}$ & $0.42^{*}$ & -0.25 & & -0.02 & $0.63^{*}$ & 0.18 & $0.56^{*}$ & 0.30 & $0.40^{*}$ & 0.27 & $0.46^{*}$ & 0.10 \\
EL & 0.17 & 0.21 & -0.06 & 0.25 & & $-0.33^{*}$ & 0.29 & $0.50^{*}$ & $0.35^{*}$ & $0.60^{*}$ & $0.33^{*}$ & $0.38^{*}$ & -0.08 \\
NRE & 0.25 & 0.11 & -0.22 & $0.43^{*}$ & $-0.33^{*}$ & & -0.05 & 0.12 & -0.04 & 0.06 & -0.22 & 0.16 & -0.04 \\
GRE & 0.26 & 0.29 & 0.20 & 0.13 & $0.54^{*}$ & $-0.33^{*}$ & & $0.59^{*}$ & 0.13 & 0.27 & $0.38^{*}$ & $0.58^{*}$ & 0.23 \\
EM & $0.42^{*}$ & $0.46^{*}$ & -0.18 & $0.85^{*}$ & $0.46^{*}$ & 0.10 & 0.26 & & $0.38^{*}$ & $0.56^{*}$ & $0.59^{*}$ & $0.89^{*}$ & $0.32^{*}$ \\
SD & 0.11 & 0.20 & -0.04 & $0.43^{*}$ & 0.24 & $0.39^{*}$ & -0.04 & 0.29 & & $0.58^{*}$ & 0.22 & $0.35^{*}$ & -0.08 \\
SM & 0.20 & 0.32 & -0.16 & $0.66^{*}$ & $0.46^{*}$ & 0.01 & 0.16 & $0.87^{*}$ & $0.43^{*}$ & & 0.22 & $0.51^{*}$ & -0.12 \\
MTG & $0.51^{*}$ & $0.50^{*}$ & 0.01 & 0.28 & 0.23 & -0.19 & $0.36^{*}$ & $0.33^{*}$ & 0.14 & 0.22 & & $0.57^{*}$ & $0.43^{*}$ \\
GME & $0.51^{*}$ & $0.51^{*}$ & -0.12 & $0.83^{*}$ & $0.44^{*}$ & 0.14 & $0.32^{*}$ & $0.93^{*}$ & 0.27 & $0.71^{*}$ & $0.40^{*}$ & & 0.26 \\
GY & $0.67^{*}$ & $0.63^{*}$ & 0.18 & 0.18 & $0.49^{*}$ & -0.19 & $0.52^{*}$ & $0.37^{*}$ & 0.09 & 0.22 & $0.59^{*}$ & $0.49^{*}$ & \\
\hline
\end{tabular}

${ }_{1}^{1} \mathrm{PH}$ : plant height $(\mathrm{m})$; EH: insertion of ear height $(\mathrm{m})$; NEP: number of ears per plant (unit); ED: ear diameter (mm); EL: ear lenght (cm); NRE: number of rows per ear (unit); NGR: number of grains per ear row (unit); SM: stem mass (g); SD: stem diameter (mm); SM: stem mass (g); MTG: mass of one thousand grains (g); GME: grain mass per ear (g); and GY: grain yield $\left(\mathrm{kg} \mathrm{ha}^{-1}\right) ;{ }^{*}$ indicates significant difference by the $\mathrm{F}$ test $(\mathrm{p} \leq 0,05)$. 
The pairs of traits that have significance in both environments were: $\mathrm{PH} \times \mathrm{EH}, \mathrm{PH} \times \mathrm{EM}, \mathrm{PH} \times \mathrm{MTG}, \mathrm{PH} \times$ GME, PH x GY, EH x MTG, ED x NRE, ED x EM, ED x SM, ED x GME, EL x EM, EL x SM, EL x GME, NGR x MTG, NGR $\times$ GME, EM $\times$ SM, EM $\times$ MTG, EM $\times$ GME, EM $\times$ GY, SD $\times$ SM, SM $\times$ GME, MTG $\times$ GME and MTG $\times$ GY, revealed very strong linear correlation (Callegari-Jacques, 2003). The correlations found for both environments were similar (Carvalho et al., 2016c).

The grain yield (GY) presented positive correlation with MTG (irrigated $r=0.59$; dry $r=0,43$ ), EM (irrigated $r=0.37$; dry $r=0.32$ ) and $\mathrm{PH}$ (irrigated $r=0.67$; dry $r=0.35$ ) in the cultivations environments, irrigated and dry. In the irrigated environment also showed a positive correlation with the traits $E H(r=0.63), E L(r=0.49), N G R$ $(r=0.52)$ and GME ( $r=0.59)$. We also observed a positive correlation of the trait mass of one thousand grains (MTG) with NGR (irrigated $r=0.36$; dry $r=0.38$ ). The use of management that maximize the use of the factors such as water, light and nutrient contributions play a fundamental role on optimizing crop production (Demétrio, Fornasieri-Filho, Cazetta, \& Cazetta, 2008).

The grain mass per ear (GME) showed a positive trend in cultivation environments, irrigated and dry, in correlation with NGR (irrigated $r=0.32$; dry $r=0.58$ ), EM (irrigated $r=0.93$; dry $r=0.89$ ), SM (irrigated $r=0.71$; dry $r=0.51$ ) and MTG (irrigated $r=0.40$; dry $r=0.57$ ). Also showing correlation with $S D(r=0.35)$ in dry environment.

The trait ear mass (EM) presented positive correlation for SM (irrigated $r=0.87$; dry $r=0.56$ ) and MTG (irrigated $r=0.33$; dry $r=0.59$ ) for the cultivation environments. Only in dry environment, positive correlation of EM with NGR ( $r=0.59)$ and with SD $(r=0.38)$. A positive correlation of the trait SD with NRE $(r=0.39)$ was observed only for irrigated environment and SM (irrigated $r=0.43$; dry $r=0.58$ ) for both tested environments.

The trait plant height $(\mathrm{PH})$ evidenced positive tends in both of cultivation environments, where they increase the traits EH (irrigated $r=0.86$; dry $r=0.62$ ), EM (irrigated $r=0.42$; dry $r=0.42$ ), MTG (irrigated $r=0.51$ dry $r=0.46$ ) and GME (irrigated $r=0.51$; dry $r=0.48$ ). It were also observed, under the irrigated environment, positive tends of the trait plant height regarding $E D(r=0.44)$ and for the trait insertion of ear height in relation to ED ( $r=0.42)$, EM $(r=0.46)$ and GME $(r=0.51)$. In dry environment the trait EH showed positive linear association with $\mathrm{SM}(\mathrm{r}=0.48)$. The correlations corrobate with the results found by Santos, Juliatti, Buiatti and Hamawaki, (2002) in which high and positive correlations were found for plant height and insertion of ear height with yield.

The trait ear length (EL) presented positive correlation with EM (irrigated $r=0.46$; dry $r=0.50$ ), SM (irrigated $r=0.46$; dry $r=0.60$ ) and GME (irrigated $r=0.44$; dry $r=0.38$ ) for both cultivation environments. In irrigated environment, a positive correlation was also observed for NGR ( $r=0.54)$, while for the dry environment, positive correlation was observed for SD ( $r=0.35)$ and MTG $(r=0.33)$. The ear diameter (ED) correlates positively with NRE (irrigated $r=0.43$; dry $r=0.63$ ), EM (irrigated $r=0.85$; dry $r=0.56$ ), SM (irrigated $r=0.66$; dry $r=0.40$ ) and GME (irrigated $r=0.83$; dry $r=0.46$ )in both cultivation environments and correlates with SD ( $r=0.43)$ only in irrigated environment.

With respect to the pairs of traits NEP x ED ( $r=-0.41)$, NEP x GME ( $r=-0.034)$, in dry environment, negative correlation was found. This shows that in exposure to water stress, there is a direct response of the crop to its reproductive organ, concomitantly reducing the diameter of the ear and the mass of the grain of the ear the higher the number of ears per plant. These results conflict with those obtained in popcorn (Galvão, Sawazaki, \& Miranda, 2000), in which positive correlations between prolificacy and grain yield were found. Also, negative correlations for EL $\times$ NRE (irrigated $r=-0.33$; dry $r=-0.33$ ) were found in both environments, independent of the environment studied, the larger the length of the ear, the fewer the number of grain rows per ear.

The canonical variables have the function of demonstrating the genetic variation among the genotypes tested and determining groups of genotypes more similar and representing their graphic dispersion through scores (Carvalho et al., 2016a; Carvalho et al., 2016b). In Figure 2, it is possible to visualize the 3D dispersion of canonical variation taking into account their scores, allowing to reveal a formation of five groups of distinct genotypes, being the group I was formed by the genotypes G11, G6, G5, G4, G2, G3 and G10, the group II was formed by the genotypes G8, G13 and G1 and the groups III, IV and V containing a single genotype, G7, G12 and G9, respectively. 


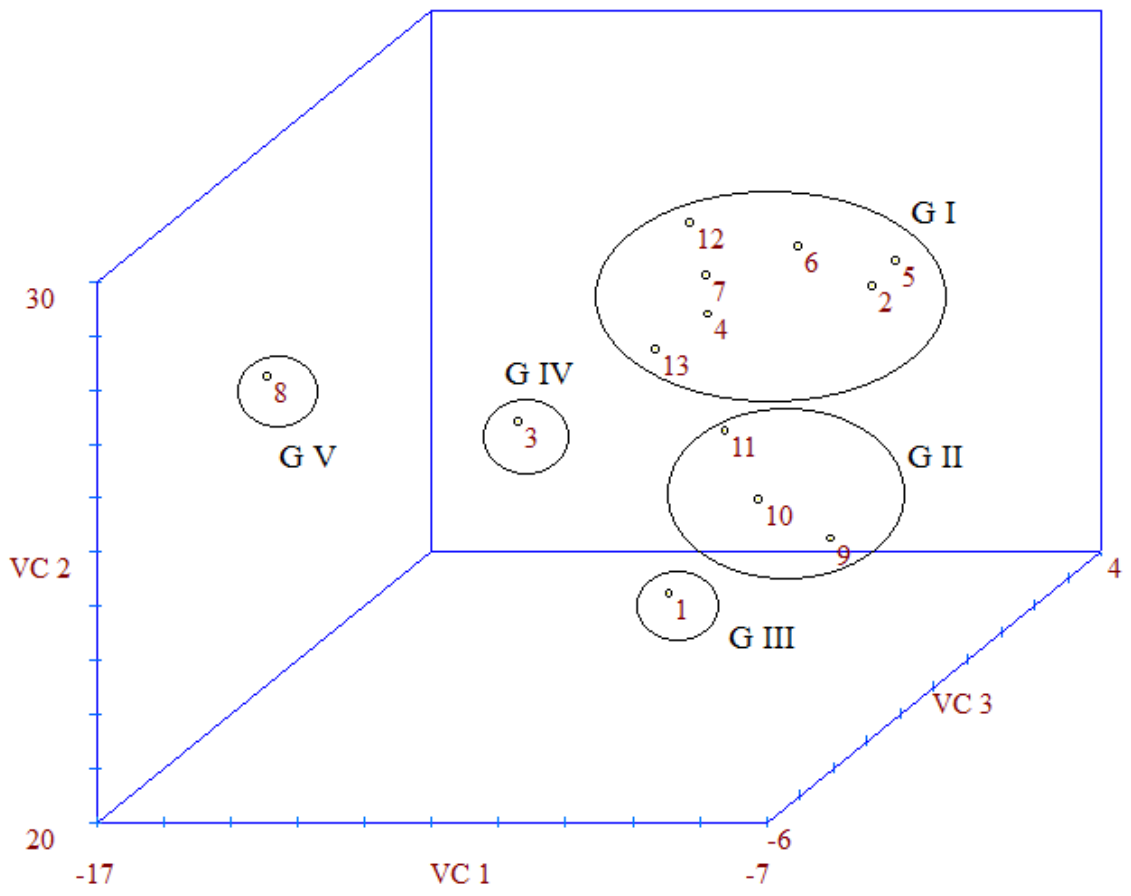

Figure 2. Demonstration of the groups of genotypes in 3D plane from the canonical variables. Campos Borges, RS.

\section{CONCLUSIONS}

The traits plant height, insertion of ear height, mass of one Thousand grains and grains yield are influenced by the genotypes $x$ environments interaction.

The irrigated environment presents superiority in relation to dry environment for all the traits studied. In general, the genotype KSP 1356 performs better than others.

The irrigated environment presents superiority than dry environment, in relation to the traits plant height, insertion of ear height, mass of one thousand grains, grain yield per hectare, ear length, ear diameter, ear mass, grains mass per ear and number of grains per ear row.

The cultivation environment changes in meaning and magnitude of associations among the yield traits in maize crop studied in this work.

It was possible to identify five groups of distinct genotypes, where the genotypes AG 9045 RR PRO ${ }^{\circ}$, AS $1572 \mathrm{PRO}^{\circ}$, AS $1656 \mathrm{PRO}^{\circ}$, DKB $245 \mathrm{PRO}^{\circ}$, DKB $250 \mathrm{PRO}^{\circ}$, and STATUS ${ }^{\circ}$, make up the same group, indicating genetic similarity between them.

\section{ACKNOWLEDGMENT}

To CNPq for the granting of a PhD scholarship.

\section{REFERENCES}

Albuquerque, C. J. B., Pinho, R. G., Borges, I. D., Souza-Filho, A. X., \& Fiorini, I. V. A. (2008). Desempenho de híbridos experimentais e comerciais de milho para produção de milho verde. Ciencia e Agrotecnologia, 32(3), 768-775. Retrieved from http://www.scopus.com/inward/record.url?eid=2-s2.070350230225\&partner|D=40\&md5=a15e8761a3929bf96e4056c35b204b93

Baretta, D., Nardino, M., Carvalho, I. R., Pelegrin, A. J., Ferrari, M., Szareski, V. J., ... Maia, L. C. (2017). Estimates of genetic parameters and genotypic values prediction in maize landrace populations by REML/BLUP procedure. Genetics and Molecular Research, 16(2), 1-14. https://doi.org/10.4238/gmr16029715 
Benjamin, J. G., Nielsen, D. C., Vigil, M. F., Mikha, M. M., \& Calderon, F. (2014). Water deficit stress effects on corn (Zea mays, L.) root:shoot ratio. Open Journal of Soil Science, 4(4), $151-160$. https://doi.org/10.4236/ojss.2014.44018

Bergamaschi, H., Radin, B., Rosa, L. M. G., Bergonci, J. I., Aragonés, R., Santos, A. O., França, S., \& Langensiepen, M. (2001). Estimating maize water requirements using agrometeorological data. Revista Argentina de Agrometeorologia, 1, 23-27.

Bergamaschi, H., Dalmago, G. A., Bergonci, J. I., Bianchi, C. A. M., Müller, A. G., Comiran, F., \& Heckler, B. M. M. (2004). Distribuição hídrica no período crítico do milho e produção de grãos. Pesquisa Agropecuária Brasileira, 39(9), 831-839. https://doi.org/10.1590/s0100-204x2004000900001

Callegari-Jacques, S. M. (2003). Bioestatística: princípios e aplicações. Porto Alegre, RS: ArtMed.

Calonego, J. C., Poleto, L. C., Domingues, F. N., \& Tiritan, C. S. (2011). Produtividade e crescimento de milho em diferentes arranjos de plantas. Revista Agrarian, 4(12), 84-90.

Cargnelutti-Filho, A., Storck, L., Riboldi, J., \& Guadagnin, J. P. (2009). Associação entre métodos de adaptabilidade e estabilidade em milho. Ciência Rural, 39(2), 340-347. https://doi.org/10.1590/s010384782008005000080

Carvalho, F. I. F., Lorencetti, C., \& Benin, G. (2004). Estimativas e Implicações da Correlação no Melhoramento Vegetal. Pelotas, RS: Editora e Gráfica UFPel.

Carvalho, I. R., Nardino, M., Demari, G. H., Follmann, D. N., Olivoto, T., Rigatti, A., Pelegrin, A. J., Szareski, V. J., Warths, C. A., Koch, F., Aisenberg, G, R., Pedó, T., Aumonde, T. Z., \& Souza, V. Q. (2016a). Multivariate analysis applied to genotype distinction in common bean. International Journal of Current Research, 8(9), 38352-38358.

Carvalho, I. R., Nardino, M., Demari, G. H., Pelegrin, A. J. De, Ferrari, M., Szareski, V. J., ... Brazil, M. (2016b). Sowing date and multivariate analisys of yield and physiological components in elite wheat genotypes. International Journal of Current Research, 8(11), 40828-40833.

Carvalho, I. R., Nardino, M., Follmann, D. N., Júnior De Pelegrin, A., Antonio, S., Kavalco, F., \& Souza, V. Q. (2016c). Análise de trilha e multivariada em milho submetido a diferentes tratamentos de sementes. Tecnologia \& Ciência Agropecuária, 10(1), 74-81. Retrieved from http://gestaounificada.pb.gov.br/emepa/publicacoes/revista-tca-emepa/edicoes/volume-10-2016/v10-n-1-marco-2016/tca10113.pdf

Carvalho, I. R., Souza, V. Q. de, Follmann, D. N., Nardino, M., \& Schmidt, D. (2014). Desempenho Agronomico. Enciclopédia Biosfera, 10(8), 1144-1153.

Cruz, C. D. (2013). GENES - Software para análise de dados em estatística experimental e em genética quantitativa. Acta Scientiarum - Agronomy, $271-276$. https://doi.org/10.4025/actasciagron.v35i3.21251

Demari, G. H., Carvalho, I. R., Szareski, V. J., Follmann, D. N., Souza, V. Q., \& Basso, C. J. (2018). Nitrogen sources and splitting in genetically modified maize hybrids. Revista de Ciencias Agroveterinarias, 17(3), 325-335. https://doi.org/10.5965/223811711732018325

Demétrio, C. S., Fornasieri-Filho, D., Cazetta, J. O., \& Cazetta, D. A. (2008). Desempenho de híbridos de milho submetidos a diferentes espaçamentos e densidades populacionais. Pesquisa Agropecuaria Brasileira, 43(12), 1691-1697. https://doi.org/10.1590/s0100-204X2008001200008

EMBRAPA - Empresa Brasileira de Pesquisa Agropecuária. (2006). Sistema brasileiro de classificação de solos (2nd ed.). Brasília, DF: Embrapa.

Galvão, J. C. C., Sawazaki, E., \& Miranda, G. V. (2000). Comportamento de Híbridos de Milho-pipoca em Coimbra, Minas Gerais. Revista Ceres, 47: 201-218. 
Hallauer, A. R., Carena, J. M., \& Miranda-Filho, J. B. (2010). Quantitative genetics in maize breeding. New York, USA: Springer.

Kluthcouski, J., Fancelli, A. L., Dourado-Neto, D., Ribeiro, C. M., \& Ferraro, L. A. (2000). Manejo do solo e o rendimento de soja, milho, feijão e arroz em plantio direto. Scientia Agricola, 57(1), 97-104. https://doi.org/https://doi.org/10.1590/S0103-90162000000100016

Leng, E. R. (1954). Effects of heterosis on the major componentes of grain yield in corn. Agronomy Journal, 46(11), 502-506. https://doi.org/https://doi.org/10.2134/agronj1954.00021962004600110007x

Lopes, A. S., Oliveira, G. Q., Souto-Filho, S. N., Goes, R. J., \& Camacho, M. A. (2011). Manejo de irrigação e nitrogênio no feijoeiro comum cultivado em sistema plantio direto. Revista Ciência Agronômica, 42(1), 51-56. https://doi.org/10.1590/s1806-66902011000100007

Nardino, M., Carvalho, I. R., Barros, W. S., Souza, V. Q., Rosa, T. C., Koch, F., Aisenberg, G. R., Aumonde, T. Z., Pedo, T., Szareski, V. J., \& Demari, G. H. (2016b). Diallel cross analysis in maize. International Journal of Current Research, 8(8), 35686-35692.

Nardino, M., Baretta, D., Carvalho, I. R., Follmann, D. N., Ferrari, M., de Pelegrin, A. J., ... de Souza, V. Q. (2017). Divergência genética entre genótipos de milho (Zea mays L.) em ambientes distintos. Revista de Ciências Agrárias, 40(1), 164-174. https://doi.org/10.19084/rca16013

Nardino, M., Carvalho, I. R., Baretta, D., Follmann, D. N., Olivoto, T., Schmidt, D., \& Souza, V. Q. De. (2016a). Genetic Parameters in maize hybrids analysis in different environments. International Journal of Current Research, 8(8), 35552-35556.

Rosa, T. C., Carvalho, I. R., Hutra, D. J., Bradebon, L. C., Sarturi, M. V. R., Rosa, J. A. G., \& Szareski, V. J. (2021). Maize breeding for abiotic stress tolerance: An alternative to face climate changes. Agronomy Science and Biotechnology, 6, 1-13. https://doi.org/10.33158/asb.r119.v6.2020

Santos, P. G., Juliatti, F. C., Buiatti, A. L., \& Hamawaki, O. T. (2002). Avaliação do desempenho agronômico de híbridos de milho em Uberlândia, MG. Pesquisa Agropecuária Brasileira, 37(5), 597-602. https://doi.org/10.1590/s0100-204×2002000500004

Santos, R. J., Bizzarri, J. H., Barbosa, A. P., \& Zucareli, C. (2017). Molybdenum application forms associated to topdressing nitrogen fertilization in the production of maize crops. Agronomy Science and Biotechnology, 3(2), 105. https://doi.org/10.33158/asb.2017v3i2p105

Sauer, A. V., Rocha, K. R., Gonçalves, R. M., Meirelles, W. F., Figueiredo, J. E. F., Marriel, I. E., \& PaccolaMeirelles, L. D. (2015). Survival of pantoea ananatis, causal agent of maize white spot disease in crop debris. Agronomy Science and Biotechnology, 1(1), 21. https://doi.org/10.33158/asb.2015v1i1p21

Schnell, F. W., \& Cockerham, C. C. (1992). Multiplicative vs. arbitrary gene action in heterosis. Genetics, 131(2), 461-469.

Silva, A. F., Schoninger, E. L., Caione, G., Kuffel, C., \& Carvalho, M. A. C. (2014). Produtividade de híbridos de milho em função do espaçamento e da população de plantas em sistema de plantio convencional. Revista Brasileira de Milho e Sorgo, 13(2), 162-173.

Sousa, R. S., Bastos, E. A., Cardoso, M. J., Ribeiro, V. Q., \& Brito, R. R. (2015). Performance of maize genotypes under water deficit. Revista Brasileira de Milho e Sorgo, 14(1), 49-60. Retrieved from http://www.abms.org.br

Szareski, V. J., Carvalho, I. R., Kehl, K., Pelegrin, A. J., Nardino, M., Demari, G. H., ... Souza, V. Q. (2018). Interrelations of Characters and Multivariate Analysis in Corn. Journal of Agricultural Science, $10(2), 187$. https://doi.org/10.5539/jas.v10n2p187 
USDA - United state Department of Agriculture. (2016). Publications corn. USDA. Retrieved from http://www.ers.usda.gov

Vencovsky, R. (1992). Associação entre caracteres. In Genética biométrica no fitomelhoramento (pp. 335434). Ribeirão Preto, SP: Sociedade Brasileira de Genética.

Received: January 21, 2021.

Accepted: March 7, 2021.

Published: May 15, 2021.

English by: Marlon Vinicius da Rosa Sarturi. 